\title{
Fluoride Contamination in Groundwater Sources of Bhagalpur Municipal Corporation Area, Bhagalpur, Bihar
}

\author{
Kumari Gouri and Sunil K. Choudhary 1 \\ Environmental Biology Research Laboratory, University Department of Botany T. M. Bhagalpur University, \\ Bhagalpur - 812007, Bihar.
}

\begin{abstract}
Higher levels of fluoride in groundwater are major concern in all over the world. Bhagalpur district of Bihar, India is identified for arsenic contamination but has equally high concentration of fluoride in groundwater. Since there are no studies to understand the present status of fluoride in groundwater in urban area under Bhagalpur Municipal Corporation (BMC), hence the present study was undertaken in 13 wards of $B M C$ to find out the level of $F^{-}$content and other physico-chemical parameters. It was observed that the fluoride concentration ranged from 1.93 to $2.98 \mathrm{mg} / \mathrm{l}, \mathrm{pH}$ from 7.2 to 8.0 , Conductivity from 922.3 to $2718.7 \mu \mathrm{s}$ whereas TDS from 569.1 to $1428.36 \mathrm{mg} / \mathrm{l}$, total hardness from 203.5 to $679 \mathrm{mg} / \mathrm{l}$, Chloride from 88.71 to 387.9 $\mathrm{mg} / \mathrm{l}$ and Bicarbonates from 32.8 to $133.4 \mathrm{mg} / \mathrm{l}$. On the basis of results obtained in the present study, it has been concluded that all physico-chemical parameters were within permissible limits whereas, in case of fluoride, all samples exceeded permissible limit of the WHO and BIS for drinking water. Therefore, drinking water of study area is not suitable for consumption without treatment.
\end{abstract}

Keywords: Groundwater, Fluoride contamination, Bhagalpur, Water pollution

\section{Introduction}

Water is the elixir of life, a precious gift of nature to the organisms. Water pollution not only affects water quality but also threats to human health, economic development and social prosperity [1]. The groundwater is believed to be comparatively much clean and pollution free than surface water. It is used for domestic, industrial water and irrigation purposes all over the world. Rapid urbanization, especially in developing countries like India, has affected the availability of quality groundwater due to its overexploitation and improper waste disposal, especially in urban areas [2]. In many towns and cities in India, groundwater is the source for multiple uses and is being supplied through municipality network and also from large number of private boreholes. According to the WHO, about $80 \%$ of all the diseases in human beings are caused by water. Once the groundwater is contaminated, its quality cannot be restored by stopping the pollutants from the source. Temporal changes in the origin and constitution of the recharged water, hydrological and human factors, may cause periodic changes in groundwater quality.

Fluorine is the lightest member of halogen group and is essential in minute quantity for normal mineralization of bone and teeth. It stimulates the growth of many plant species but on other hand if taken up in excessive amount may be toxic to plants and animals. Major health issues due to drinking fluoride contaminated water include dental fluorosis, teeth mottling, skeletal fluorosis and deformation of bone in human beings. Around 200 million people from 25 nations have health risks because of high fluoride in groundwater. In India alone about 62 million people are at risk due to incidence of dental and skeletal fluorosis [3]. Dental fluorosis is endemic in about $50 \%$ states of India with the problem most pronounced in the states of Andhra Pradesh, Bihar, Gujarat, Madhya Pradesh, Punjab, Rajasthan, Tamil Nadu, and Uttar Pradesh [4]. According to one study, 30$50 \%$ of districts of Bihar are affected by fluorosis. According to Bihar government 8,188 villages in 11 districts have excess fluoride in groundwater [5].

The main source of drinking water for Bhagalpur city is underground water. The present supply of water by Bhagalpur Municipal Corporation is 21 MLD through hand pumps and deep bore wells, and the per capita water supply for the city is 38 LPCD. Bhagalpur Municipal Corporation (BMC) has 51 wards and symptoms of dental and skeletal fluorosis in residents of some wards located in southern part of the city indicate fluoride contamination in groundwater sources in these wards and that is a major concern for the health of the people of these wards. A number of studies are available about fluoride contamination of groundwater from various parts of India and Bihar [4, 6, 7, 8, 9, 10,11], But no systematic study has been done for fluoride mapping of groundwater sources for the area under BMC. Keeping these points into account, the present study was undertaken to determine underground water quality in wards of BMC prone to fluoride contamination. 


\subsection{Study Area}

\section{Materials And Methods}

Bhagalpur city $\left(25^{\circ} 7^{\prime}\right.$ to $25^{\circ} 30^{\prime} \mathrm{N} \& 86^{\circ} 37^{\prime}$ to $\left.86^{\circ} 30^{\prime} \mathrm{E}\right)$ is situated at $184 \mathrm{~m}$ above mean sea level on the southern bank of River Ganga (Fig.1). Bhagalpur is covering about 30.18 sq. km. area with an average population density of 1180 men per sq. $\mathrm{km}$. The population of town is 4, 25,443 as per Census 2011. Ground water (hand pumps and deep bore wells) is the main source of drinking water. The climate is tropical and is characterized by hot summer $\left(19.4^{\circ} \mathrm{C}-38^{\circ} \mathrm{C}\right)$ and pleasant winter $\left(8.6^{\circ} \mathrm{C}-28.4^{\circ} \mathrm{C}\right)$. The average annual rainfall is $1200 \mathrm{~mm}$ with maximum rainfall confined to monsoon months and almost no rains in winter.

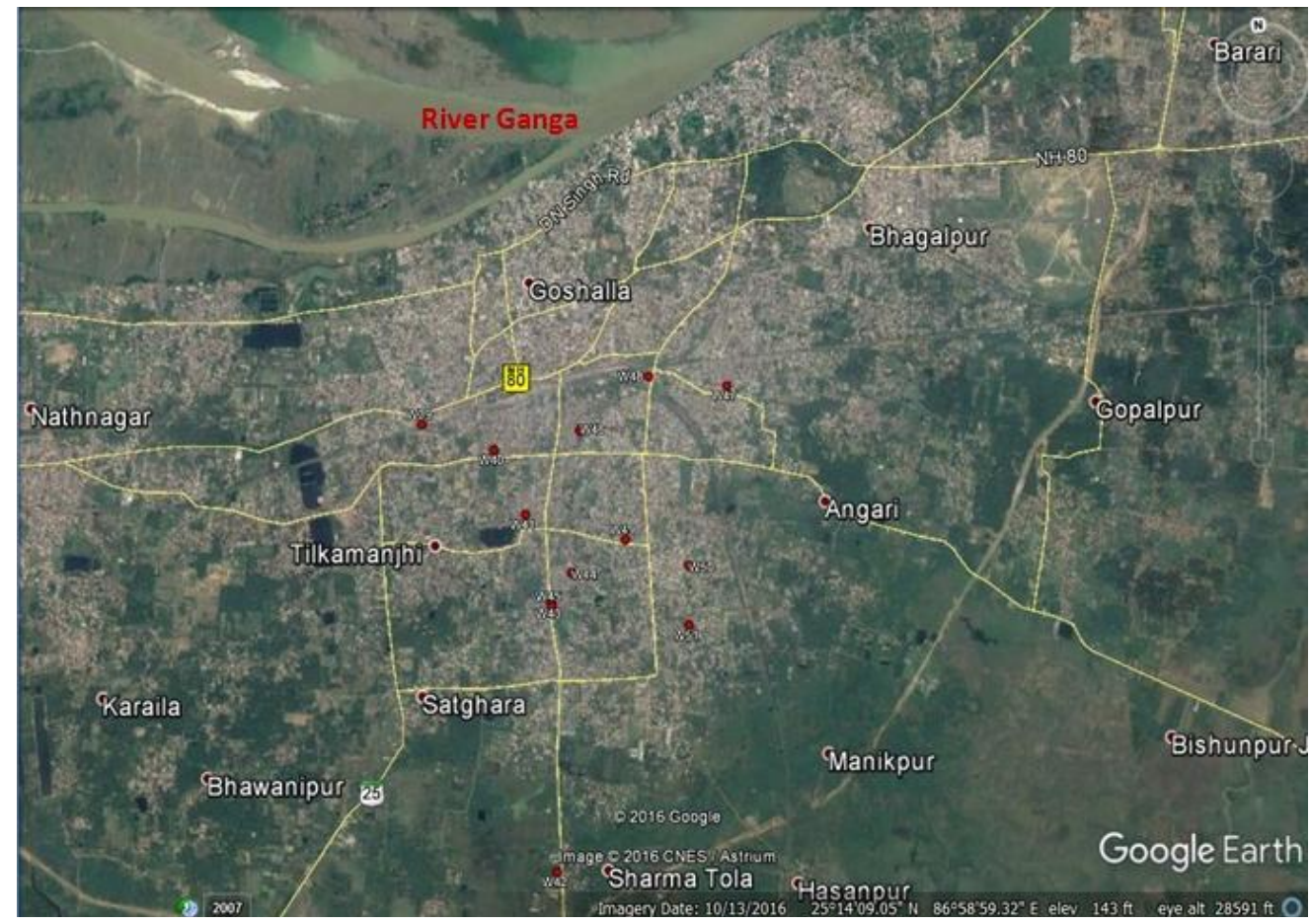

Fig: 1. Location map of study area with sampling points

\subsection{Sample collection}

65 groundwater samples (5 water samples from each ward) were collected from 13 different wards (Wards 39-51) under BMC in 2011. Samples were collected in pre-cleaned bottles which were again rewashed at sampling sites. Hand pump and deep bore well water samples were collected after pumping the water for 510 minutes. In the case of open wells, water samples were collected at $30 \mathrm{~cm}$ below the water level. The $\mathrm{pH}$ and water temperature of samples were recorded on the spot. For further analysis, collected samples were transported to Environmental Biology Research Laboratory of University Department of Botany, T. M. Bhagalpur University, Bhagalpur. Fluoride analysis was done by Spectroquant Colorimeter Picco (Merck 1.73606.0001). Physico-chemical parameters of groundwater were analyzed using Standard methods [12 \& 13].

\section{Results And Discussion}

The variations in physico-chemical parameters of selected groundwater sources are depicted in Table-1 and Figs. $2 \& 3$. The water temperature ranged from 21.06 to $24.4{ }^{\circ} \mathrm{C}$. It was higher $\left(24.4{ }^{\circ} \mathrm{C}\right)$ in wards $49 \& 50$ and lower in ward $39\left(21.06^{\circ} \mathrm{C}\right)$. The $\mathrm{pH}$ ranged from 7.2 to 8.0 with higher values in wards $41 \& 44(8.0)$ and lower in ward 39 (7.2), similar to the results obtained by Ramesh \& Soorya [14]. Electrical conductivity of water ranged from 922.32 to $2718.7 \mu$ s. The highest value was found in ward $43(2718.7 \mu \mathrm{s})$ and lowest in ward $46(922.32 \mu \mathrm{s})$. The values of TDS ranged from 569.1 to $1428.4 \mathrm{mg} / \mathrm{l}$. It was higher $(1428.4 \mathrm{mg} / \mathrm{l})$ in ward 39 and lower in ward 46 (569.1 mg/l), similar to the findings of Sharma \& Patel [15]. EC and TDS values exceeded the desirable limit but were well within permissible limit $(2000 \mathrm{mg} / \mathrm{l})$ in all the samples. Total hardness of water is a measure of dissolved $\mathrm{Ca}^{2+}$ and $\mathrm{Mg}^{2+}$ in water expressed as $\mathrm{CaCO}_{3}$. Water hardness has no known adverse effects; however, it causes more consumption of detergents at the time of cleaning and some evidence indicates its role in heart disease. The values of total hardness ranged from $203.5 \mathrm{mg} / \mathrm{l}$ to $679 \mathrm{mg} / \mathrm{l}$. It was maximum in the sample of ward 51 and minimum in the ward 44. The results show all samples within permissible limit (600 $\mathrm{mg} / \mathrm{l})$ except in sample of ward $51(679 \mathrm{mg} / \mathrm{l})$. The concentration of fluoride and total hardness in the present study are inversely related in the present study similar to the previous studies [4]. 
Fluoride Contamination in Groundwater Sources of Bhagalpur Municipal Corporation Area,

Table 1: Average value of physico-chemical parameters and fluoride content in groundwater sources of 13 BMC Wards (5-groundwater samples analysed in each ward) during 2010-11.

\begin{tabular}{|c|c|c|c|c|c|c|c|c|c|c|c|}
\hline $\begin{array}{l}\text { Sampling } \\
\text { Ward No. }\end{array}$ & $\begin{array}{l}\text { Depth } \\
\text { (Feet) }\end{array}$ & $\begin{array}{l}\text { Water } \\
\text { temp }\left({ }^{\circ} \mathrm{c}\right)\end{array}$ & $\mathrm{pH}$ & $\mathrm{EC}(\mu \mathrm{s})$ & TDS & $\mathrm{TH}$ & $\mathrm{Cl}^{-}$ & $\mathrm{HCO}_{3}$ & $\mathrm{NO}_{3}{ }^{-} \mathrm{N}$ & $\mathrm{PO}_{4}^{-} \mathrm{P}$ & $\mathrm{F}^{-}$ \\
\hline 39 & 80.0 & 21.06 & 7.2 & 2179.53 & 1428.4 & 596.9 & 387.9 & 91.8 & 0.03 & 0.037 & 2.32 \\
\hline 40 & 225.0 & 23.93 & 7.6 & 1111.23 & 613.5 & 288.8 & 88.71 & 75.4 & 0.03 & 0.037 & 2.17 \\
\hline 41 & 306.7 & 23.26 & 8.0 & 1338.36 & 869.76 & 286.5 & 117.4 & 71.4 & 0.03 & 0.037 & 2.20 \\
\hline 42 & 166.7 & 23.0 & 7.4 & 1328.8 & 1256.7 & 484.7 & 240.8 & 133.4 & 0.03 & 0.037 & 2.26 \\
\hline 43 & 186.7 & 23.93 & 7.4 & 2718.7 & 1083.1 & 322.3 & 201.9 & 71.4 & 0.03 & 0.037 & 2.08 \\
\hline 44 & 283.3 & 24.0 & 8.0 & 1329.34 & 1288.2 & 203.5 & 135.2 & 78.8 & 0.037 & 0.03 & 2.97 \\
\hline 45 & 150.0 & 23.26 & 7.4 & 957.5 & 927.4 & 572.5 & 239.7 & 50.2 & 0.037 & 0.034 & 2.30 \\
\hline 46 & 72.5 & 23.13 & 7.4 & 922.32 & 569.1 & 236.8 & 109.1 & 61.0 & 0.037 & 0.04 & 1.93 \\
\hline 47 & 140.0 & 23.0 & 7.5 & 1785.4 & 1112.6 & 383.7 & 277.2 & 32.8 & 0.037 & 0.04 & 2.75 \\
\hline 48 & 96.7 & 23.86 & 7.6 & 1269.45 & 1122.6 & 379.9 & 194.0 & 48.13 & 0.037 & 0.034 & 2.98 \\
\hline 49 & 143.3 & 24.4 & 7.7 & 1978.06 & 1165.1 & 527.4 & 230.6 & 105.0 & 0.037 & 0.034 & 2.02 \\
\hline 50 & 156.7 & 24.4 & 7.8 & 1898.53 & 1391.2 & 559.7 & 208.5 & 130.7 & 0.037 & 0.034 & 1.97 \\
\hline 51 & 95.0 & 23.8 & 7.9 & 1685.53 & 1125.3 & 679 & 274.2 & 124.7 & 0.037 & 0.034 & 2.02 \\
\hline
\end{tabular}

All parameters expressed in $\mathrm{mg} / \mathrm{l}$ except Depth, Temperature, $\mathrm{pH} \&$ Conductivity

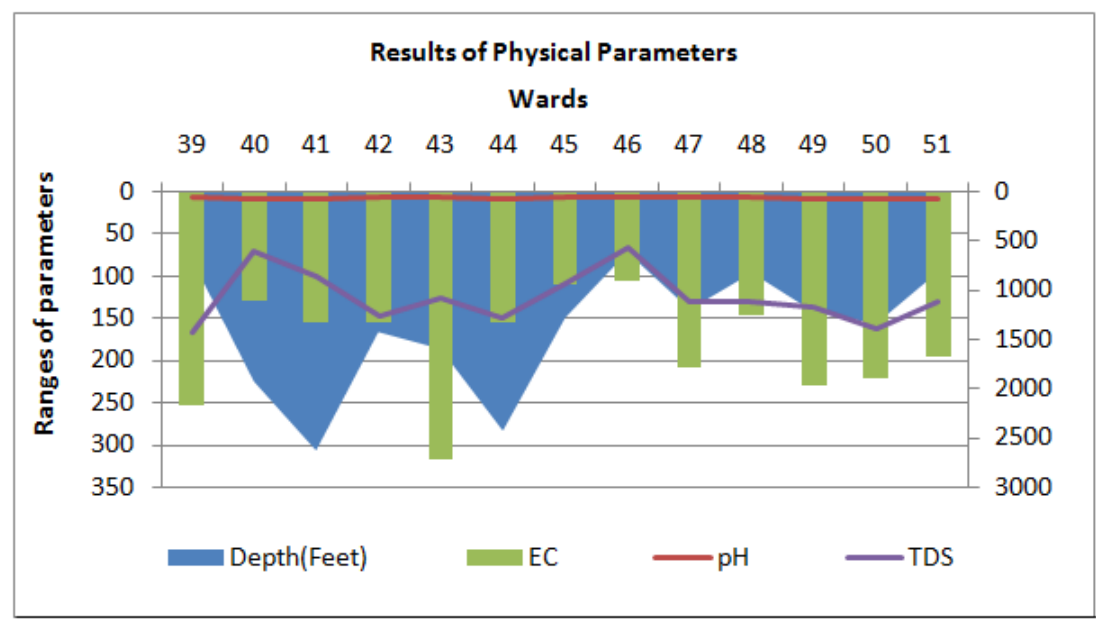

Fig: 2. Physical parameters of drinking water samples from 13 wards of BMC

The concentration of Chloride was observed in the range of 88.71 to $387.9 \mathrm{mg} / \mathrm{l}$. Chloride values were within permissible limit in all studied samples. It was higher $(387.9 \mathrm{mg} / \mathrm{l})$ in ward 39 and lower $(88.71 \mathrm{mg} / \mathrm{l}) \mathrm{in}$ ward 40. The Carbonate was absent in all the water samples analyzed. Bicarbonate ranged from 32.8- 133.4 $\mathrm{mg} / \mathrm{l}$. It was observed that the rise and fall of total alkalinity mostly corresponded with that of bicarbonates. Therefore, Bicarbonate and Total Alkalinity values were higher $(133.4 \mathrm{mg} / \mathrm{l})$ in the sample of ward 42 and lower (32.8) in ward 47. The overall, high $\mathrm{pH}$, bicarbonate, and less hardness in groundwater lead to leaching of fluoride which results in increase in the concentration of fluoride in groundwater as established in the present study also. Nitrate-nitrogen and Phosphate-phosphorus concentration were very low and therefore not expected to degrade the drinking water quality.

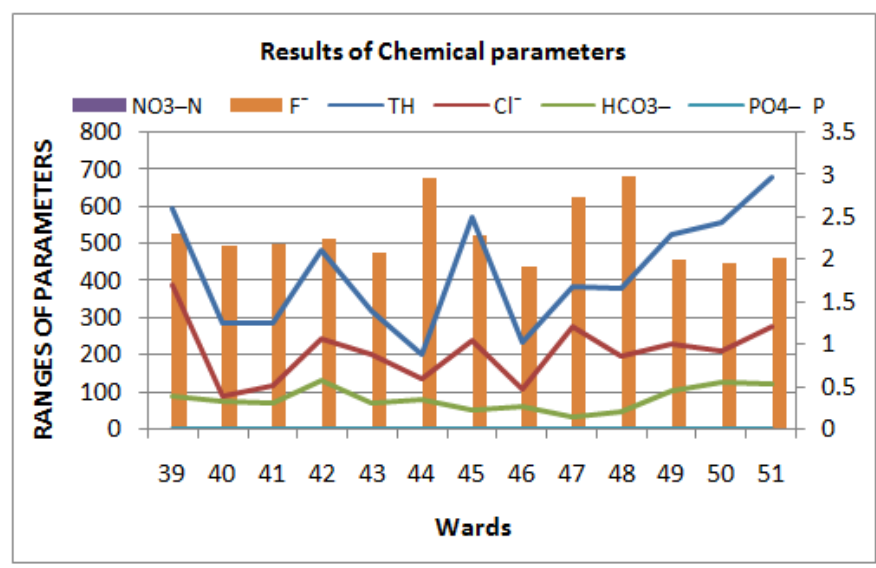

Fig: 3. Chemical parameters of drinking water samples from 13 wards of BMC 
Fluoride Contamination in Groundwater Sources of Bhagalpur Municipal Corporation Area,

Table 2: Correlations matrix of physico-chemical parameters of groundwater in Bhagalpur Municipal Corporation (2010-2011)

\begin{tabular}{|c|c|c|c|c|c|c|c|c|c|c|c|}
\hline & $\begin{array}{l}\text { Depth } \\
\text { (Feet) }\end{array}$ & $\begin{array}{l}\text { Water temp } \\
\left({ }^{\circ} \mathrm{C}\right)\end{array}$ & $\mathrm{pH}$ & $\mathrm{EC}$ & TDS & $\mathrm{TH}$ & $\mathrm{Cl}^{-}$ & $\mathrm{HCO}^{-}$ & NO3-N & $\begin{array}{l}\text { PO4- } \\
\mathrm{P} \\
\end{array}$ & $\mathrm{F}^{-}$ \\
\hline $\begin{array}{l}\text { Depth } \\
\text { (Feet) }\end{array}$ & 1 & & & & & & & & & & \\
\hline $\begin{array}{l}\text { Water temp } \\
\left({ }^{\circ} \mathrm{C}\right)\end{array}$ & 0.32 & 1 & & & & & & & & & \\
\hline $\mathrm{pH}$ & 0.61 & 0.61 & 1 & & & & & & & & \\
\hline $\mathrm{EC}$ & -0.11 & -0.05 & -0.13 & 1 & & & & & & & \\
\hline TDS & -0.10 & -0.14 & 0.06 & 0.57 & 1 & & & & & & \\
\hline $\mathrm{TH}$ & -0.53 & -0.19 & -0.16 & 0.28 & 0.51 & 1 & & & & & \\
\hline $\mathrm{Cl}^{-}$ & -0.56 & -0.57 & -0.44 & 0.52 & 0.68 & 0.78 & 1 & & & & \\
\hline HCO3- & -0.04 & 0.14 & 0.26 & 0.25 & 0.47 & 0.52 & 0.27 & 1 & & & \\
\hline NO3-N & -0.35 & 0.40 & 0.24 & -0.25 & 0.07 & 0.15 & 0.01 & -0.15 & 1 & & \\
\hline PO4- P & -0.28 & -0.46 & -0.57 & 0.04 & -0.45 & -0.18 & 0.04 & -0.30 & -0.36 & 1 & \\
\hline $\mathrm{F}^{-}$ & 0.17 & -0.08 & 0.09 & -0.19 & 0.27 & -0.32 & 0.04 & -0.50 & 0.23 & -0.31 & 1 \\
\hline
\end{tabular}

Correlation Significant at $* 5 \%$ level. TDS $=$ Total Dissolved Solids, EC $=$ Electrical Conductivity, TH= Total Hardness, $\mathrm{HCO}_{3}{ }^{-}=$Bicarbonate, $\mathrm{PO}_{4}-\mathrm{P}=$ Phosphate, $\mathrm{NO}_{3}-\mathrm{N}=$ Nitrate, $\mathrm{Cl}^{-}=$Chloride, $\mathrm{F}^{-}=$Fluoride

Table 3: Percentage increase in fluoride level in groundwater of Bhagalpur Municipal Corporation (2010-2011)

\begin{tabular}{|l|l|l|l|}
\hline $\begin{array}{l}\text { Sampling } \\
\text { Ward No. }\end{array}$ & $\begin{array}{l}\mathbf{F}^{-} \\
(\mathbf{p p m})\end{array}$ & $\begin{array}{l}\text { Std. F level } \\
(\mathbf{p p m})\end{array}$ & $\begin{array}{l}\text { \% } \\
\text { increase }\end{array}$ \\
\hline 39 & 2.32 & 1.5 & 54.7 \\
\hline 40 & 2.17 & 1.5 & 44.5 \\
\hline 41 & 2.19 & 1.5 & 46.5 \\
\hline 42 & 2.26 & 1.5 & 50.7 \\
\hline 43 & 2.08 & 1.5 & 38.7 \\
\hline 44 & 2.97 & 1.5 & 98.0 \\
\hline 45 & 2.29 & 1.5 & 53.3 \\
\hline 46 & 1.93 & 1.5 & 28.7 \\
\hline 47 & 2.75 & 1.5 & 83.3 \\
\hline 48 & 2.98 & 1.5 & 98.7 \\
\hline 49 & 2.02 & 1.5 & 34.4 \\
\hline 50 & 1.97 & 1.5 & 31.3 \\
\hline 51 & 2.02 & 1.5 & 34.9 \\
\hline
\end{tabular}

Fluoride concentration in the study area varied between 1.93 to $2.98 \mathrm{mg} / \mathrm{l}$. It was highest (2.98 $\mathrm{mg} / \mathrm{l}) \mathrm{in}$ ward 48 followed by ward $44(2.97 \mathrm{mg} / \mathrm{l})$ and lowest $(1.93 \mathrm{mg} / \mathrm{l})$ in the sample of ward 46 . The WHO has recommended the permissible limit of fluoride in drinking water to be $1.5 \mathrm{mg} / \mathrm{l}$, whereas, BIS has recommended an upper acceptable limit of $1.0 \mathrm{mg} / \mathrm{l}$ of $\mathrm{F}^{-}$as desirable concentration of fluoride in drinking water, which can be extended to $1.5 \mathrm{mg} / 1$ of $\mathrm{F}^{-}$in case no alternative source of water is available. In the present study, almost all groundwater samples (source of drinking water) exceeded desirable/permissible limit as prescribed by WHO/BIS for $\mathrm{F}^{-}$in drinking water. Fluoride values exceeded by $28.7-98.7 \%$ which is almost double the values recommended by WHO and BIS. The requirement of fluoride in daily uses varies from country to country depending on geography and the age of the people too [9]. Water sources having fluoride concentration of more than $1.5 \mathrm{mg} / \mathrm{l}$ are not suitable for drinking purposes. In the present study all the groundwater samples analyzed for wards 39 - 51 exceed the permissible limit of fluoride $(1.5 \mathrm{mg} / \mathrm{l})$ in drinking water. The elevated levels of fluoride in the groundwater sources in the investigated wards of Bhagalpur Municipal Corporation appear to have adverse effects on the residents of these wards. This is substantiated by the reported cases of dental and skeletal fluorosis in the people from these wards (39 to 51). Similar findings were also reported by Kumar and Kumar [16]. Correlation matrix shows that Fluoride was positively correlated to Depth (0.049275), pH (0.639912), EC (0.086708), TDS (0.246149), $\mathrm{Cl}^{-}(0.240897), \mathrm{NO}_{3}{ }^{-} \mathrm{N}(0.731781)$ and negatively correlated to water temperature, $\mathrm{HCO}_{3}{ }^{-}$and $\mathrm{PO}_{4}-\mathrm{P}$ (Table- 2).

\section{Conclusion}

Physico-chemical analysis of groundwater sources (drinking water sources) of the 13 wards under Bhagalpur Municipal Corporation suggest that all the physico-chemical parameters are within safe limits except that of fluoride which is above permissible limit as prescribed by WHO/BIS for drinking water. The excess fluoride concentration in the study area (Wards 39-51) may be attributed to the geological formation in the area. The weathering of rocks and leaching of fluoride bearing minerals might be the major reasons which may have contributed to the elevated concentration of fluoride in groundwater sources of Bhagalpur Municipal Corporation. Therefore, the present study indicates that groundwater sources in wards $39-51$ of Bhagalpur Municipal Corporation are not fit for drinking purpose. Elevated levels of fluoride in groundwater sources might 
be possibly responsible for reported cases of dental and skeletal fluorosis in the residents of investigated BMC wards. The study was conducted to generate baseline data on fluoride concentration in groundwater sources of BMC. Further study is required to estimate fluoride concentration both in pre- and post-monsoon period and associated health risk because of intake of water with elevated level of fluoride. The amount of fluoride in food, vegetables and dental products used in the locality also needs to be measured.

\section{Acknowledgements}

The authors wish to acknowledge Dr. Braj Nandan and Mr. Manish Kumar of Environmental Biology Research Lab of T. M. Bhagalpur University for critical discussion and suggestions for improving the manuscript. Lab and Library facilities provided to the authors by the Head, University Department of Botany, T. M. Bhagalpur University, Bhagalpur is gratefully acknowledged.

\section{References}

[1] M. Milovanovic, Water quality assessment and determination of pollution sources along the Axios/Vardar River, Southeastern Europe, Desalination, 213, 2007, 159-73.

[2] C. R. Ramakrishnaiah, C. Sadashivaiah and G. Ranganna, Assessment of Water Quality Index for the Groundwater in Tumkur Taluk, Karnataka State, India, E Journal of Chemistry, 6(2), 2009, 523-530.

[3] S. K. Andezhath, A. K. Susheela and G. Ghosh, Fluorosis management in India: The impact due to networking between health and rural drinking water supply agencies, (IAHS-AISH Publication, 1999) 260, 159- 165.

[4] K. Brindha, R. Rajesh, R. Murugan and L. Elango, Fluoride contamination in groundwater in parts of Nalgonda District, Andhra Pradesh, India, Environ Monit Assess 172, 2011, 481-492.

[5] A. K. Susheela, Fluorosis in India, the magnitude and severity of the Problem, Sci Dev Env. 1987, $147-157$.

[6] S. Das, B. C. Mehta, P. K. Das and S. K. Srivastava, Fluoride Hazards in Groundwater of Orissa, India, Indian Environ Hlth (1), 2009, 40-46.

[7] R. Agrawal and T. I. Khan, Groundwater quality and Fluoride content in Sikarithesil of Dausa District, The Ecoscan 4(2\&3), 2010, 225-226.

[8] S. Yasmin, S. Monterio, P. A. Ligimol and D. D'Souza, Fluoride contamination and fluorosis in Gaya Region of Bihar, India, Department of Zoology, Patna Women's College, Bailey Road, Patna, Bihar, India, Current Biotica 5(2), $2011,232-236$.

[9] T. Ramachandramoorthy, V. Sivasankar and R. Gomathi, Fluoride and other parametric status of groundwater samples at various locations of the Kolli Hills, Tamilnadu, India, J. IPHE, India, (3), 2008, 50-56.

[10] A. K. Jha and U. Kumar, A case study of arsenic and fluoride contamination in groundwater of Bhagalpur District, Journal of Chemical and Pharmaceutical Research. 6(11), 2014, 735-738.

[11] N. N., Jha, S. N., Poddar, T. N., Mandal and A. K. Sinha, Fluoride content in groundwater and fluorosis in Human population in Katihar District of North Bihar, India, Fresh water Biol. 9(2), 1997, 98-100.

[12] APHA, Standard Methods for the examination of water and waste water analysis (21 ${ }^{\text {st }}$ edition American Public Health Association, AWWA-WEF, Washington D C, 2005).

[13] R. K. Trivedy and P. K. Goel, Chemical and Biological Methods for water pollution studies (Environmental Publication, Karad, 1986).

[14] K. Ramesh and V. Soorya, Fluoride Contamination in Drinking Water in Palacode Region, Tamil Nadu. International Journal of Research in Chemistry and Environment, 2(1), 2012, 116-123.

[15] D. N. Sharma and J. N. Patel, Evaluation of Groundwater Quality Index of the Urban Segments of Surat City, India, I. J. GEO. (1), 2010, 4.

[16] A. Kumar and V. Kumar, Fluoride Contamination in Drinking Water and its Impact on Human Health of Kishanganj, Bihar, India, Res. J. Chem. Sci. 5(2), 2015, 76-84. 